\title{
Challenging the call: Should sports governing bodies be subject to judicial review?
}

\author{
Ben Cisneros ${ }^{1} \mathbb{0}$
}

Published online: 3 March 2020

(c) The Author(s) 2020

\begin{abstract}
English law is settled in its view that Sports Governing Bodies ("SGBs") are not amenable to judicial review, following the Court of Appeal decision in $R v$ Disciplinary Committee of the Jockey Club, ex $p$ Aga Khan. However, this article argues that, 27 years on from the leading decision, the issue merits reconsideration owing to flaws in judicial reasoning and, in particular, the subsequent growth of the government's involvement in sport. Moreover, the availability of judicial review in other jurisdictions and against other self-regulatory organisations suggests that the position of SGBs in English law is anomalous. Since Aga Khan, the courts have developed a private law "supervisory jurisdiction" which somewhat accounts for the absence of judicial review but, building on the work of Michael Beloff QC (among others), this article considers the substantive and procedural limitations of private law in challenging SGBs, finding that judicial review may be a preferable forum for sporting litigants. The paper also provides the opportunity to reflect upon the nature of the public-private divide in English law today.
\end{abstract}

Keywords Judicial review $\cdot$ Sports governing bodies $\cdot$ Supervisory jurisdiction $\cdot$ Public law $\cdot$ Sports litigation

\section{Introduction}

The past 30 years have seen a vast evolution in the world of sport. Significant investment, both public and private, has caused the industry to flourish, and there is increasingly more at stake for all those involved: athletes, clubs, agents, sponsors and fans-not to mention the State. In 1997, Ebsworth J commented that "sport today is big business" ; but if it was big then, it is prodigious now. Sport is a booming industry and a central part of modern life. It is "part of our national identity". ${ }^{2}$

With so much riding on every match, race or tournament, it is vital that there is good governance within each sport. This is the job of Sports Governing Bodies ("SGBs") at national and international level-for example, in England, the Football Association (FA) or the Rugby Football Union (RFU). These incorporated associations have a monopoly in their sporting market, ${ }^{3}$ with extensive regulatory powers enabling them to exclusively determine and apply the rules

Ben Cisneros

bencisneros97@gmail.com

1 Law Graduate of Selwyn College, Cambridge, UK affecting athletes, coaches, clubs, agents (collectively "participants") and even supporters. The propriety of these competences is not in doubt, but, given the industry's growth, the need for accountability is greater than ever.

This paper will focus on the use of judicial review ("JR") $)^{4}$ as a way of challenging SGB decisions and rules, to achieve legal accountability. English law is settled in its view that SGBs are not amenable to JR following the Court of Appeal ("CA") decision in $R v$ Disciplinary Committee of the Jockey Club, ex p Aga Khan ${ }^{5}$ but, as Beloff et al. suggest, "it is not clear that the last word has been said on the subject". 6 This paper will argue that, 27 years on from the leading decision, the issue merits reconsideration owing to flaws in judicial reasoning and, in particular, the subsequent growth of the government's involvement in sport. Moreover, the availability of JR in other jurisdictions and against other

1 Jones $v$ Welsh Rugby Football Union (The Times, 6 March 1997).

2 Department for Digital, Culture, Media \& Sport, Sporting FutureA New Strategy for an Active Nation (Policy Paper) Chap. 1.

3 Russell v Duke of Norfolk [1949] 1 All ER 109, 119 (Denning LJ).

4 "Judicial Review" shall be defined in this paper as the remedy available under s.31 Senior Courts Act 1981, regulated by Part 54 of the Civil Procedure Rules 1998.

5 [1993] 1 WLR 909.

${ }^{6}$ Beloff et al. (2012), p. 46. 
self-regulatory organisations suggests that the position of SGBs in English law is anomalous.

Since Aga Khan, the courts have developed a private law "supervisory jurisdiction" which somewhat accounts for the absence of JR, but, as it will be argued, private law remedies suffer from substantive and, particularly, procedural limitations, such that JR may be a preferable forum for sporting litigants. The standing requirements and hearing process of JR give it particular appeal in the sports context, and it can be seen as a more efficient alternative to private law actions. The approach of New Zealand, allowing challenges to SGBs in public or private law, ${ }^{7}$ should be followed.

In Finnigan $v$ NZRFU, Cooke $\mathrm{J}$, as he then was, considered that SGBs fall into a "special area where... a sharp boundary between public and private law cannot realistically be drawn" ${ }^{\prime 8}$ and, ultimately, it is this fundamental issue which has made this area of law so fraught with controversy. Though this paper does not aim to assess the propriety of a divide between public and private law, which an orthodox view of English law would prescribe, ${ }^{9}$ the analysis undertaken herein allows conclusions to be drawn about the softer nature of that divide today.

\section{The state of play}

Whether a body may be subject to JR is a question which has troubled courts for decades. Determining the precise scope of JR is incredibly difficult, and it can only be inferred from "the catalogue of the borderline cases". ${ }^{10}$

Various criteria for determining amenability have emerged over the past 100 years, with the traditional approach being the "source of power" test. ${ }^{11}$ Under this formula, if the power to make the decision in question was derived from statute or the Royal Prerogative, it would be amenable to JR but, if the power was rooted in contract, it would be excluded from public law. ${ }^{12}$ However, the law in this area has developed such that it is now proper to speak of a "public function" test. ${ }^{13}$

\footnotetext{
7 Armstrong $(2008)$.

8 [1985] 2 NZLR 159, 179.

${ }^{9}$ E.g. Woolf (1986).

10 Wade and Forsyth (2014), p. 532.

11 E.g. Law v National Greyhound Racing Club [1983] 1 WLR 1302; CCSU v Minister for Civil Service [1985] 1 AC 374.

12 Hampshire County Council v Beer t/a Hammer Trout Farm [2004] 1 WLR 233 [12].

$13 R$ (Holmcroft) v FCA and Barclays [2018] EWCA Civ 2093 [40]; Williams (2017b), 15-26.
}

\subsection{The public function test}

The potential scope of JR was extended in $R v$ Panel on Takeovers and Mergers, ex $p$ Datafin, ${ }^{14}$ in which Lloyd LJ held:

I do not agree that the source of the power is the sole test whether a body is subject to judicial review...the source of the power will often, perhaps usually, be decisive. If the source of power is a statute, or subordinate legislation under a statute, then clearly the body in question will be subject to judicial review. If, at the other end of the scale, the source of power is contractual, as in the case of private arbitration, then clearly the arbitrator is not subject to judicial review... But in between these extremes there is an area in which it is helpful to look not just at the source of the power but at the nature of the power. If the body in question is exercising public law functions, or if the exercise of its functions have public law consequences, then that may... be sufficient to bring the body within the reach of judicial review. ${ }^{15}$

This decision led to the emergence of the public function test, which has since been formally adopted into the Civil Procedure Rules ("CPR"). ${ }^{16}$ As such, a claim for JR can only be brought in respect of an enactment, a decision, an action or a failure to act relating to the exercise of a "public function". ${ }^{17}$

The precise meaning of this term has been the subject of much deliberation, and there remains some uncertainty. In Datafin itself, Sir John Donaldson MR spoke simply of a "public element, which can take many forms", ${ }^{18}$ while in the more recent case of Hampshire County Council v Beer t/a Hammer Trout Farm, ${ }^{19}$ Dyson LJ spoke of the need for sufficient public "flavour" to bring a body's decision within the reach of public law. ${ }^{20}$ This criterion is "very broad, not to say question-begging", ${ }^{21}$ but there is a growing body of case law from which principles can be extracted. ${ }^{22}$

In Beer, the CA held that a decision of Hampshire Farmers Markets Limited, a private company, had sufficient public flavour in order to be amenable to JR, largely owing to its close relationship with Hampshire County Council and the

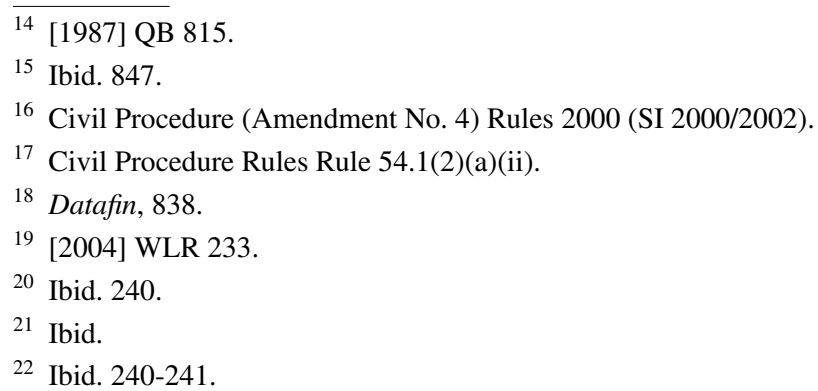


fact that it was regulating access to a public market. Similarly, the International Stock Exchange of the United Kingdom ("UK") and the Republic of Ireland (a limited company) was held amenable to JR owing to its wider "public" role. $^{23}$

In Datafin, the Panel on Take-overs and Mergers was found to be susceptible to JR. The panel was a self-regulating body in charge of enforcing the City Code on Take-overs and Mergers, with no statutory, prerogative or common law powers. The court noted the panel's immense power and thought the fact it was not a statutory body was a "complete anomaly" 24 explicable only as an accident of history. It was also key that the government had "incorporated the panel into its own regulatory network" $" 25$ and that private law control would be ineffective. ${ }^{26}$ Therefore, though Sir John Donaldson MR suggested that amenability depends simply on finding a "public element", the reasoning in the cases suggests a narrower approach ${ }^{27}$-there will only be a public function where certain "public" features can be identified.

Yet there may also be uncertainty about what "publicness" is. As Hoffman LJ stated in Aga Khan, in line with previous authorities ${ }^{28}$ public law and public interest are not the same thing:

Private power may affect the public interest... But that does not subject it to the rules of public law. ${ }^{29}$

The court in Aga Khan considered that, to be amenable to JR, the power must be "governmental". ${ }^{30}$ It may be that this interpretation is too narrow, ${ }^{31}$ but, for the purposes of this paper, it suffices that "public" means "governmental".

Therefore, it follows from the CPR and an established body of case law that the modern test for amenability to JR is one of the public functions. Though the source of the power may be relevant, the existence of a contractual relationship is not necessarily inconsistent with $\mathrm{JR},{ }^{32}$ provided that the rights asserted are not purely contractual. ${ }^{33}$

\footnotetext{
${ }^{23} R v$ The International Stock Exchange of the UK and the Republic of Ireland, ex p Else (1982) Ltd [1993] QB 534.

${ }^{24}$ Datafin, 835.

25 Ibid.

${ }^{26}$ Elliott and Varuhas, (2017), p. 133.

27 Ibid.

${ }^{28} R v$ East Berkshire Health Authority, ex $p$ Walsh [1985] QB 152, 164.

29 Aga Khan, 932.

30 Ibid. 931.

31 Elliott and Varuhas (2017), pp. 133-138.

${ }^{32} R$ (McIntyre) $v$ Gentoo [2010] EWHC 5 (Admin) [29]. ${ }^{33}$ Walsh. I.e. Where there is no public element.
}

\subsection{The position of SGBs}

Traditionally, SGBs have fallen outside the scope of JR, following the CA decision in Law v National Greyhound Racing Club. ${ }^{34}$ Primarily, this was justified on the basis that the source of the SGB's power was contractual and the appropriate remedy was, therefore, in private law. This approach was applied by the courts in, inter alia, $R v$ Football Association of Wales, ex $p$ Flint Town United $F C^{35}$ and $R v$ Football Association, ex $p$ Football League. ${ }^{36}$

However, the issue returned to the CA in Aga Khan, where the applicant sought to challenge a decision by the disciplinary committee of the Jockey Club (an SGB) to disqualify his horse for failing a drugs test. Notwithstanding the functional shift instigated by Datafin, the position in Law was upheld and JR denied. Hoffman LJ, as he then was, held that the SGB operated "entirely in the private sector and its activities are governed by private law". ${ }^{37}$

While he made clear that private clubs are capable of also exercising public powers, he found that "there is no public source for any of [the Jockey Club's] powers". ${ }^{38}$ The court heavily emphasised the existence of a contractual relationship between the parties and noted that the applicant would likely have a remedy in private law. ${ }^{39}$ Farquharson LJ stressed that "public law remedies do not lie against domestic bodies, as they derive solely from the consent of the parties". 40

For JR to lie, according to Hoffman LJ, the power may be de facto or de jure, but it must be "governmental in nature". ${ }^{41}$ As Sir Thomas Bingham MR stated:

the Jockey Club...has not been woven into any system of governmental control of horseracing...This has the result that while the Jockey Club's powers may be described as, in many ways, public they are in no sense governmental. $^{42}$

A final thread of the CA's reasoning was the rejection of the argument that "but for" Jockey Club's existence, the government would be forced to intervene to regulate horseracing and, as such, its powers could be considered "public". Farquharson LJ straightforwardly dismissed the idea that

\footnotetext{
34 [1983] WLR 1302.

35 [1991] COD 44.

36 [1993] 2 All E.R. 833.

37 Aga Khan, 931.

38 Ibid.

39 Ibid. 924.

40 Ibid. 928-933.

41 Ibid. 931.

42 Ibid. 923.
} 
"any governmental body would assume control of racing", 43 while Sir Thomas Bingham MR accepted that "the government would probably be driven to create a public body to do so" $" 44$ but ultimately held that this did not alter the fact that its powers derived from contract and were thus not "governmental". 45

This approach has been definitive in English law and has been followed consistently, ${ }^{46}$ surviving its most recent challenge in $R$ (Mullins) v Jockey Club (No. 1). ${ }^{47}$

\section{The case for judicial review}

Given the case law to date, SGBs are highly unlikely to be considered amenable to JR without a Supreme Court ("UKSC") decision overruling Aga Khan. ${ }^{48}$ It is submitted that there is a strong case for such a decision and that the existing line of authority has been a "wrong turn" 49 in English law. This Part will re-evaluate Aga Khan, criticising the court's reasoning, drawing on support from analogous English case law and that of other jurisdictions. SGBs perform a public function now more than ever, and so, properly applying the test laid out in Part 2.1, should be amenable to JR.

It is important to establish at the outset that, though the argument herein will refer to SGBs in the abstract, each case would turn on its own facts and it is likely that some SGBs would be more readily susceptible to JR than others. ${ }^{50}$ However, given the fundamental similarities between the position and powers of SGBs, and the broad government interest in sport as a whole, it is legitimate to predicate the argument on the basis that they would generally be treated alike.

\subsection{Re-evaluating Aga Khan}

The argument for overruling Aga Khan rests on two main propositions: that it places too much weight on the source of SGB power and fails to appreciate its public flavour-something which has become more pronounced in subsequent years. These central strands of argument shall be considered in turn, though it is impossible to separate them entirely.

\footnotetext{
43 Ibid. 930.

44 Ibid. 923.

45 Ibid. 923-924.

46 Jones $v$ WRFU.

47 [2005] EWHC 2197 (Admin).

48 Beloff et al. (2012), p. 262.

49 Ibid. p. 264.

${ }^{50}$ E.g. Football is referenced in statute and attracts far greater public interest than any other sport.
}

\subsubsection{The source of the power}

Firstly, it is argued that Aga Khan focuses too much on the source of the powers of SGBs, as opposed to their function, which sits uncomfortably with the decision in Datafin and subsequent authorities. ${ }^{51}$ The court emphasised that JR was unavailable because the source of the power was a consensual, contractual relationship between the parties. However, this approach fails to recognise the true nature of the relationship between participants and SGBs, as well as the nature of SGB power.

The "contract" is fictional To describe the relationship between a participant and an SGB as purely contractual is artificial and unrealistic. SGB regulations bind participants regardless of any express contract and may even preclude individuals participating altogether. ${ }^{52}$ In Modahl $v$ British Athletics Federation, ${ }^{53}$ the CA held that there are three ways in which a contractual link can be established between an SGB and an athlete: the "club basis" (a chain of mutually interdependent contracts starting with an employment contract with a sports club in which the athlete agrees to be bound by the SGB regulations), the "participation basis" (a contract is implied by virtue of the athlete's participation under the regulations) or the "submission basis" (a contract is implied by virtue of the athlete's submission to the SGB's regulatory procedures). ${ }^{54}$ Though there will be exceptions, ${ }^{55}$ in the archetypal case, there is no express contract with the SGB. Indeed, in Modahl, Parker LJ dissented, considering there to be no real intention to create legal relations, nor any consideration to speak of. ${ }^{56}$

As Lord Denning MR observed in Enderby Town FCv Football Association, ${ }^{57}$ this "contract" is simply a "fiction created by the lawyers to give jurisdiction". ${ }^{58}$ It is necessary for the effective administration of sport, ${ }^{59}$ as there is no statutory scheme by which to otherwise enforce the rules. SGBs, as argued below, are de facto public bodies: it is simply an accident of history that they must rely on the contractual jurisdiction. Using a fiction created to increase oversight of SGBs to now deny such oversight via JR lacks

\footnotetext{
51 Morgan (2012), 105.

${ }^{52}$ Nagle v Feilden [1966] 2 QB 633.

53 [2001] EWCA Civ 1447.

54 James (2017), pp. 31-32.

${ }^{55}$ E.g. England rugby players will be contracted to the RFU when playing for the national team.

56 Modahl, [72-83].

57 [1971] Chap. 591.

58 Ibid. 606.

59 James (2017), p. 29.
} 
common sense - the law should be "mature enough" to "do away with" such fictions. ${ }^{60}$

The lack of genuine consent There is also a lack of genuine consent to SGBs' jurisdiction, undermining further the argument against JR in Aga Khan. Each SGB has its own set of regulations ${ }^{61}$ which cover an incredibly broad array of issues including discipline, doping, intermediaries, corruption, betting, safety, safeguarding, player licensing, eligibility, transfers, club ownership and finance, as well as the rules of the sport itself. They are even able to limit freedom of expression. ${ }^{62}$ As Lord Denning MR observed, such regulations are, in reality, a "legislative code" 63 going far beyond a contractual regime. They regulate an entire sphere of conduct, both commercial and personal, and give SGBs the enormous power to impose sanctions which can range from 1-week suspensions, to lifetime bans ${ }^{64}$ as well as points deductions, fines, or even relegation.

Enormous power alone, though, is insufficient to undermine the purported contractual relationship. Freedom of contract is a fundamental feature of English contract law, and, as such, parties are free to agree to all these things. The key point, however, is that there is no "agreement" in the true sense of the word-these are rules which are imposed rather than consented to.

One might argue this is true of most contracts entered into in the modern day-for example, employment or consumer contracts. However, the enormous power of SGBs is doubly significant because they hold a monopoly. As such, participants are in an incredibly weak position and have no choice but to accept the regulations. ${ }^{65}$ This is ultimately "Hobson's choice"-terms are imposed on a "take it or leave it" basis, and the latter is no option at all. By contrast, in the employment and consumer contexts, there will ordinarily be other job opportunities and other products to buy in the market. ${ }^{66}$ In such monopolistic circumstances, "consensual submission" provides no basis on which to exclude $\mathrm{JR},{ }^{67}$ as there is no genuine consent.

This argument was rejected by Farquharson LJ in Aga Khan. He suggested that the "reality of the consent" was not undermined, as the imposition of rules was necessary

\footnotetext{
60 Nagle v Feilden, 646.

61 E.g. FA Handbook; RFU Regulations.

62 Boyes (2017).

63 Enderby Town, 606; Breen v Amalgamated Engineering Union [1971] 2 QB 175, 190.

64 E.g. Former UK Athletics coach George Skafidas was given a lifetime ban from all sport in 2016.

65 Beloff and Kerr (1996).

66 In any event, these areas are also regulated heavily by statute.

67 Pannick (1992), 2-5.
}

for the administration of sport. ${ }^{68}$ The latter is certainly true, so it would be dangerous to suggest that there is insufficient consent for the "contract" to be binding, but it must nonetheless be recognised that the consent is artificial. ${ }^{69}$ The court here took an "unusually two-dimensional view"70 which is particularly unsatisfactory because "when genuine consent is absent, this is precisely when abuse of power is most likely, and judicial protection most needed". ${ }^{71}$ The court should instead have focused on the unavoidability of submission to the decision-maker. ${ }^{72}$

Farquharson LJ's view was echoed by the CA in Stretford $v$ Football Association, ${ }^{73}$ but the European Court of Human Rights recently took a different approach, ${ }^{74}$ holding that an arbitration clause enclosed in an SGB's regulations had not been agreed in a "free and unambiguous manner"75 and, thus, the athlete's rights under Art.6(1) ECHR had not been validly waived. Though this was a human rights case, it nevertheless recognised that consent to SGB regulations is not real-a decision English courts will have to take into account. $^{76}$

Should consent preclude judicial review? It is also arguable that the reasoning in Aga Khan is unsound because it could be applied to all forms of voluntary activity subject to a statutory licensing regime. ${ }^{77}$ It could be said that an applicant to a statutory licensing authority "voluntarily" submits to its jurisdiction, as they could choose not to engage in the relevant activity. Of course, in such cases, "consensual submission" would not preclude JR. Nor should it for SGBs.

That said, Sir John Donaldson MR said in Datafin that "bodies whose sole source of power is a consensual submission to its jurisdiction" (emphasis added) will be excluded from the scope of JR. ${ }^{78}$ Consensual submission is not a statutory licensing authority's sole source of power. However, the same is arguably true of SGBs, as they wield de facto public power-power which is impliedly devolved, or perhaps even expressly derived, from government, as explained below.

Indeed, the source of the power cannot be fully separated from the nature of the power. The dicta in Datafin properly

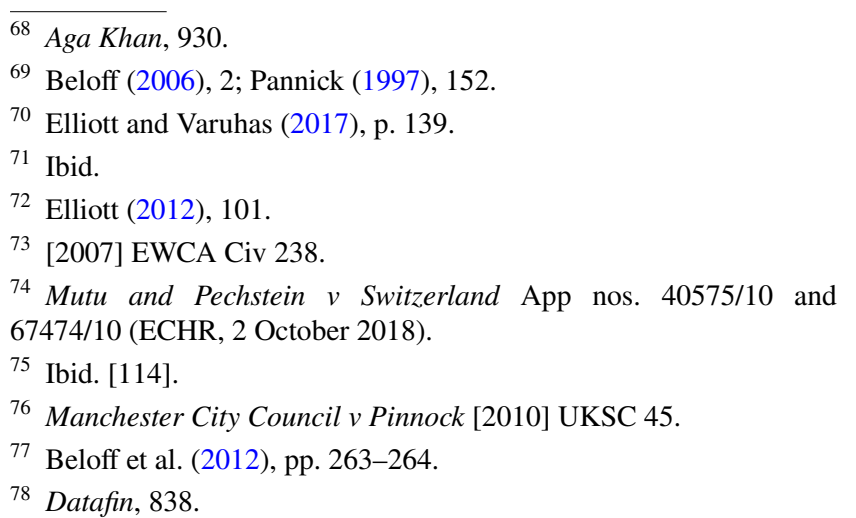


suggest that where a body is exercising a public function, there will not be a purely contractual relationship - the very publicness of the power means that public law is applicable, regardless of any contract. ${ }^{79}$

Given the fictional nature of the "contract" and the artificiality of the consent to SGBs' jurisdiction, placing such weight on the source of the power as the court did in Aga Khan is inappropriate ${ }^{80}$ - particularly when the modern test for amenability requires a more functional approach, and the existence of a contract has been held not to be fatal to JR claims in subsequent decisions. ${ }^{81}$ SGBs' power may formally be predicated on contract, but the reality is that they are performing a public function.

\subsubsection{Satisfying the public function test}

Having established that there should be no contractual and/ or consensual bar to an application for JR against an SGB, it can now be argued that SGBs should be amenable to JR because they satisfy the public function test set out in Part 2.1. Though there has always been a strong case for SGBs satisfying this test, ${ }^{82}$ it has now become irrefutable owing to the change in government policy, which allows the missing "governmental" element to be found.

The enormous public interest in sport gives it great potential as a government policy tool to achieve social and political objectives, and it is undoubtedly used to promote national standing. ${ }^{83}$ Indeed, throughout modern history, sport has been used as a bargaining tool in international relations. ${ }^{84}$ This immediately suggests a public element, but more specific arguments can be made. These arguments are ones which have often been put forward, but it is submitted that the wider context has changed such that they can now be made more forcefully.

The "But For" argument Firstly, it is submitted that, but for the work of SGBs, the government-owing to its direct interest in sport and its governance-would itself be driven to regulate sport, demonstrating that SGBs are, in reality, carrying out a public function. This is a test frequently used to determine amenability ${ }^{85}$ but was answered in the negative

\footnotetext{
${ }^{79}$ Elliott and Varuhas (2017), p. 140.

80 Elliott (2012).

${ }^{81}$ Clark $v$ University of Lincolnshire and Humberside [2000] 1 WLR 1988; R (McIntyre) v Gentoo (n 32).

82 Beloff and Kerr (1996); Beloff et al. (2012), p. 268.

${ }^{83}$ Boyes (2017), 364.

${ }^{84}$ E.g. Sporting boycotts of apartheid South Africa, Cold War Olympic boycotts.

85 Pannick (1992), 5.
}

in Aga Khan ${ }^{86}$ endorsing the view of Rose $\mathrm{J}$ in $R v F A$, exp Football League:

I find no sign of underpinning directly or indirectly by any organ or agency of the State or any potential government interest...nor is there any evidence to suggest that if the FA did not exist the State would intervene to create a public body to perform its functions. ${ }^{87}$

With respect, it is suggested that such views are out of date and merit reconsideration. The government today has a clear, direct interest in sport, ${ }^{88}$ and there is plenty to suggest that, in the absence of SGBs, they would intervene.

In the first decade of the twenty-first century, Exchequer funding of sport reached unprecedented levels ${ }^{89}$ and, in 2002, sport was properly recognised in government, as a key policy objective of the Department for Digital, Culture, Media and Sport ("DCMS"). ${ }^{90}$ The DCMS is now primarily responsible for administering public sports policy, albeit at arm's length via several non-departmental public bodies ${ }^{91}$ ("NDPBs"), including Sport England and UK Sport. The traditional view that " the government does not and should not run sport' no longer reflects the complexities of modern sports policy", ${ }^{92}$ nor the reality of its implementation in the UK.

The 2015 DCMS "Sporting Future" policy paper gave some telling indications of the government's direct interest in sport, setting out the government's strategy of "harnessing the power of sport for the good of our whole society", ${ }^{93}$ emphasising sport's personal, economic and social impact. Sport's role in the pursuit of public health goals is significant, ${ }^{94}$ and SGBs are often key to implementing such policy. ${ }^{95}$

In addition, as the 2015 paper announced, government agencies Sport England and UK Sport have developed a new Code for Sports Governance setting out the levels of "transparency, accountability and financial integrity" required of SGBs seeking public funding. ${ }^{96}$

\footnotetext{
${ }_{86}$ Supra, note 43; criticised by Beloff and Kerr (1996).

${ }^{87}$ [1993] 2 All E.R. 833.

${ }^{88}$ Gardiner et al. (2012), pp. 89-90.

${ }^{89}$ Lewis and Taylor (2014), p. 10.

90 Ibid. p. 22.

91 Ibid. pp. 23-24

92 Ibid. p. 10.

93 Supra, note 2, Chap. 3.

94 Boyes (2017), 363-364.

95 Supra, note 2, Chap. 1.

96 'A Code for Sports Governance' (uk sport) <http://www.ukspo rt.gov.uk/resources/governance-code> Accessed 14 March 2019.
} 
Furthermore, the DCMS Committee ("DCMSC") 97 has conducted detailed enquiries into matters of concern within sport, including homophobia, ${ }^{98}$ women and sport, ${ }^{99}$ matchfixing in tennis ${ }^{100}$ and, currently, sports governance more broadly. ${ }^{101}$ The DCMSC's very existence demonstrates a government interest in sport, but the nature of its enquiries reveals a particular desire to ensure accountability. This is perhaps best exemplified by its 2018 "combatting doping in sport" report which followed an intrusive and very public enquiry, centred around British Cycling. ${ }^{102}$

Indeed, the government is particularly concerned with anti-doping. In 2003, the UK government signed the Copenhagen Declaration on Anti-Doping in Sport, in which they agreed to formally recognise and implement the World AntiDoping Code ("WADC") and, in 2006, ratified the International Convention against Doping in Sport. Moreover, the government showed its dedication to the anti-doping movement by creating the UK Anti-Doping agency in 2009, another NDPB. It is responsible for the sample collection, testing and whereabouts programmes of the majority of UK athletes. By funding an anti-doping programme and by signing up to internationally agreed anti-doping objectives, the government seeks to promote fair and clean sport, further highlighting its direct interest.

A further example of government expansion into sport has been in the field of anti-corruption. The Gambling Commission-another NDPB_-created the Sports Betting Intelligence Unit ("SBIU") in 2005 to monitor gambling and uphold integrity in sport, while s.42 of the Gambling Act 2005 was introduced by the government specifically to target match-fixing. ${ }^{103}$ Section 42 makes it a criminal offence to "cheat at gambling", ${ }^{104}$ which includes interference with a sporting event to which the gambling relates. ${ }^{105}$

More recently, in 2014, the government published the UK Anti-Corruption Plan, which set out a cross-governmental approach to tackle corruption, including specific measures

\footnotetext{
97 The Parliamentary Select Committee to which the DCMS is accountable.

98 DCMSC, Homophobia in Sport (Report, HC 113, 2017).

99 DCMSC, Women and Sport (Report, HC 513, 2014).

100 DCMSC, 'Match Fixing in Tennis' (Parliament) https://www. parliament.uk/business/committees/committees-a-z/commons-select/ culture-media-and-sport-committee/inquiries/parliament-2015/inqui ry/. Accessed 14 March 2019.

101 DCMSC, 'Sport governance inquiry' (Parliament) https://www. parliament.uk/business/committees/committees-a-z/commons-selec t/digital-culture-media-and-sport-committee/inquiries/parliament -2017/sports-governance-17-19/. Accessed 14 March 2019.

102 DCMSC, Combatting doping in sport (Report, HC 366, 2018).

103 Ibid. p. 143.

104 S.42(1) Gambling Act 2005.

105 S.42(3) Gambling Act 2005.
}

addressing corruption in sport. Principal among these was the Sport and Sports Betting Integrity Action Plan, launched by the Gambling Commission in 2015, which delineates the responsibilities of, inter alia, SGBs and government in combatting corruption. Such an initiative is yet another example of how the government's interest and involvement in sport has grown since the early 1990s.

There is thus a strong argument that "but for" SGBs, the government would be driven to regulate sport itself, such is its interest in the sector. SGBs are therefore exercising a public function.

The "Interwoven" argument Moreover, as required by the courts in Datafin and Aga Khan, SGBs are "woven into the fabric of public regulation". 106

For example, the role of administering anti-doping rules is not exclusive to UKAD. All SGBs adopt the WADC into their own regulations and assume responsibility, along with UKAD, for its implementation. Indeed, it is often the SGBs themselves that act as prosecutor in doping cases and who are responsible for enforcing bans imposed by the National Anti-Doping Panel.

Much the same point can be made with regard to anti-corruption. Working closely alongside the police and the SBIU, SGBs have taken a proactive role in the fight against corruption. ${ }^{107}$ All major SGBs have extensive anti-corruption regulations ${ }^{108}$ aimed at deterring and punishing conduct which is corrupt, or potentially so, through sporting sanctions. While not all conduct punished by SGBs is also criminal, the most serious cases will be and, by implementing such comprehensive regulations, SGBs play an important role in preventing criminal behaviour.

However, SGBs' jurisdiction does not cover those who may be involved from outside of sport in corruption and, thus, an effective approach to tackling the problem requires cooperation with, inter alia, law enforcement agencies and government. ${ }^{109}$ As aforementioned, this joined-up approach is explicitly recognised in the Sport and Sports Betting Integrity Action Plan, which imposes certain requirements on each of the key stakeholders, including the Gambling Commission-a government agency. In this context, too, SGBs are therefore woven into the fabric of public regulation.

Moreover, the SGBs of sports such as rugby, football, boxing and other contact sports have exclusive jurisdiction over an area which would ordinarily be governed by the criminal law. Following $R v$ Barnes, ${ }^{110}$ violent conduct in

\footnotetext{
106 Aga Khan, 923.

107 Ibid. p. 145.

108 E.g. RFU Regulation 17; FA Betting Rules 2019-2020.

109 Thompson (2016).

110 [2004] EWCA Crim 3246.
} 
the sporting arena is exempted from criminal sanction, as long as it remains within reasonable bounds of the rules. As such, these SGBs fulfil the function of policing those bounds by ensuring that violent conduct in breach of the rules is sanctioned appropriately. In other words, a jurisdiction is carved out of the criminal law for certain SGBs. This specific function has strong public flavour in itself, given the otherwise public nature of the sanctions the conduct would attract, and it is also an example of how SGBs are woven into public regulation.

Indeed, this is highlighted explicitly in the memorandum of understanding between the FA, FAW, the Crown Prosecution Service and the Association of Chief Police Officers. ${ }^{111}$ It recognises that there are often situations in which football's SGBs will have concurrent jurisdiction with law enforcement agencies and sets out the terms of their cooperation in relation to both investigating and sanctioning.

A further example is the statutory regulation of football hooliganism, which was the culmination of prolonged efforts by the government, in combination with the police and football's SGBs, to gain control of the issue. ${ }^{112}$ For the offences under the Football (Offences) Act 1991 to be made out, or for a Football Banning Order to be imposed under the Football Spectators Act 1989, the match with which the relevant conduct is connected must be a "designated" football match-ultimately, a game under the authority of the SGBs. ${ }^{113}$ In this regard, football's SGBs are inextricably integrated into governmental regulation.

Of course, these latter examples are confined to certain sports and as such can only advance the argument insofar as those specific SGBs are concerned. However, there is strong evidence of a more general integration of SGBs into the public sphere and, in any event, as noted above, ${ }^{114}$ it may be that certain SGBs are more susceptible to JR than others.

Implied devolution of power One might nonetheless argue that the government has still abstained from directly intervening in day-to-day sports regulation; it is left to private bodies and as such falls properly within the private sector. Indeed, in 2018, the government rejected a petition to create an independent regulator for English football, on the basis that the existing authorities do a satisfactory job,

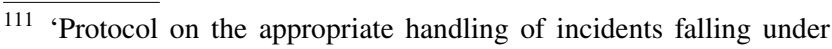
both criminal and football regulatory jurisdiction' (The FA, 23 December 2013) <http://www.thefa.com/-/media/files/pdf/thefa-2013-14/governance/crown-prosecution-fa-faw.ashx?la=en> Accessed 4 November 2019.

112 James (2017), p. 223.

113 Ibid. p. 243.

114 Supra, note 50.
}

negating any need or desire to create a government body. ${ }^{115}$ Government:

believes sports are best governed by modern, transparent, accountable and representative governing bodies, able to act decisively in the long-term interest of each sport and its participants ${ }^{116}$

However, this reflects an implied devolution of governmental power. By actively choosing not to legislate in this field, owing to its satisfaction with the work of the FA, the government is impliedly granting the SGB power to continue regulating football, in the same way that Lloyd LJ considered the panel in Datafin to be operating. ${ }^{117}$ The same can be said of many SGBs, though there isn't such explicit evidence. The government has a strong interest in sport's regulation, but, due to their expertise and natural independence, it considers existing SGBs better-placed to perform that function and thus, far from abstaining, gives them implied authority to continue doing so. That sport is administered by private bodies is simply an accident of history. ${ }^{118}$

In any event, SGBs' receipt of public funding, via Sport England and UK Sport, suggests that their power may be somewhat derived from government expressly.

Public interest Finally, the "massive public interest in sport" ${ }^{119}$ plays a role in creating public flavour. The fact that sport can affect people's lives in so many ways, as fans, participants and aspiring participants, means that the public at large has an interest in its good governance. Though "public interest" has been considered distinct from "public law", ${ }^{120}$ it is suggested that the two can be linked. Public interest affects government decision-making and ultimately drives public policy. As such, an area of significant public interest is almost inevitably an area of government interest, such that its regulation will have public flavour. Sport is one such area.

Moreover, all SGBs act, or at least purport to act, in the public interest. ${ }^{121}$ They commonly cite as their object the promotion and growth of the sport throughout their territory. ${ }^{122}$ This may include commercialisation, but the primary objective remains the development of the sport itself, which

\footnotetext{
115 DCMS, The Government must introduce an independent regulator for English football (Petition Response, 29 March 2018) <https ://petition.parliament.uk/petitions/213108?reveal_response=yes $>$ Accessed 14 March 2019.

116 Ibid.

117 Datafin, 849.

118 Anderson (2006), 183.

119 Lewis and Taylor (2014), p. 10.

120 Supra, note 29.

121 Lewis and Taylor (2014), p. 826.

122 E.g. RFU Rules, FA Articles of Association.
} 
is in the public interest. SGBs thus perform a function which is "other-regarding" 123 — something typical of governmentwhich might further suggest that a public function is being exercised. ${ }^{124}$

There are thus multiple ways to demonstrate that SGBs wield de facto public power. Undeniably, as the sports industry has grown exponentially over the past two decades, so has the government's interest in it. In Aga Khan, Hoffman LJ considered that the English legislator's attitude to racing was "akin to its attitude to religion... something to be encouraged but not the business of government". ${ }^{125}$ This statement can no longer hold true. Aga Khan merits reconsideration: SGBs are performing a public function.

\subsubsection{Supporting case law}

The argument premised herein is not altogether unsupported by English case law. Indeed, in Aga Khan itself, Farquharson $\mathrm{LJ}$ refused to "discount the possibility that in some special circumstances the remedy might lie", ${ }^{126}$ while Lord Woolf MR similarly left the possibility open in Wilander $v$ Tobin (No. 2) ${ }^{127}$ It is suggested that the new-found governmental element provides such special circumstances.

In $R v$ Jockey Club, ex p RAM Racecourses,${ }^{128}$ Brown $\mathrm{J}$ held that he would have allowed JR of the Jockey Club but for the fact that he was bound by the decision in Law. He considered the function of regulating a sport "strikingly akin to the exercise of a statutory licensing power" and, as such, had "no difficulty in regarding it as one of a public law body". ${ }^{129}$ The court in $R v$ Disciplinary Committee of the Jockey Club, ex p Massingberg-Mundy ${ }^{130}$ considered itself similarly bound, but otherwise would have allowed JR. More recently, in Jockey Clubv Buffham, Gray J described the Jockey Club as a "public authority in every sense". ${ }^{131}$ The Jockey Club - no longer the regulator of horseracing in Britain-was no different in its role and powers than other SGBs.

Support can also be derived from the "borderline cases", particularly those in which "self-regulatory bodies" have been held amenable to JR. For example, the Advertising

\footnotetext{
123 Williams (2017a), 664.

124 Ibid. 657.

125 Aga Khan, 932.

126 Ibid. 930.

127 [1997] 2 CMLR 346, 355.

128 [1993] 2 All ER 225.

129 Ibid. 247.

130 [1993] 2 All ER 207.

131 [2003] 2 WLR 178.
}

Standards Authority ("ASA") 132 and the former Press Complaints Commission ${ }^{133}$ have been considered to be subject to JR, as has the Code of Practice Committee of the British Pharmaceutical Industry ("CPC"). ${ }^{134}$ All are/were private, self-regulatory organisations without any statutory basis but which regulate(d) important parts of public life and were woven into the fabric of public regulation.

Indeed, in $R v$ Advertising Standards Authority Ltd, ex $p$ Insurance Service plc, ${ }^{135}$ Glidewell LJ, in holding that the ASA was subject to JR, said:

The Authority has no powers granted to it by statute or at common law, nor does it have any contractual relationship with the advertisers whom it controls. Nevertheless it is clearly exercising a public law function which, if the Authority did not exist, would no doubt be exercised by the Director General of Fair Trading.

For the reasons outlined in Part 3.1, it is argued that SGBs are analogous.

In Professional Counselling Aids, ${ }^{136}$ Popplewell J reluctantly found the CPC amenable to JR, emphasising that Datafin had "enlarge[d] enormously" 137 the scope of JR and placing reliance on the decision in Insurance Service. The latter was endorsed specifically in Aga Khan. ${ }^{138}$

Likewise, the Bar Council was held reviewable in $R$ $v$ General Council of the Bar, ex $p$ Percival $^{139}$, a body "empowered by its rules to prosecute [complaints] before the disciplinary tribunal as an adjudicating body exercising powers delegated by the judges". ${ }^{140}$ The Council has an important role in regulating the Bar-a field in which the government certainly has an interest, given the way barristers affect the determination of individuals' fundamental rights. But for the Bar Council it seems incredibly likely that a statutory authority-like the Solicitors Regulatory Authority - would be created. SGBs perform a similar role, regulating an area of government interest and quasi-judicially determining fundamental rights.

\footnotetext{
${ }^{132} R v$ Advertising Standards Authority, ex $p$ Vernons Organisation [1992] 1 WLR 1289.

${ }^{133} R$ v Press Complaints Commission ex p Stewart-Brady [1997] EMLR 185.

${ }^{134} R v$ Code of Practice Committee of the Association of the British Pharmaceutical Industry ex p Professional Counselling Aids (1990) 10 BMLR 21.

${ }^{135} R$ v Advertising Standards Authority Ltd, ex $p$ Insurance Service plc [1990] 2 Admin LR 77.

136 Supra, note 135.

137 Ibid. 39.

138 Aga Khan, 931-932.

139 [1991] 1 QB 212.

140 Ibid. 228-229.
} 
Furthermore, parallels can be drawn between the position of SGBs and the limited company subjected to JR in Beer. In the same way that Hampshire Farmers Markets Ltd. regulated access to a market in which there was significant public interest, so too do SGBs. Indeed, the market to which SGBs regulate access is an awful lot larger, as it operates at national level.

More recently, the Independent Press Standards Organisation ("IPSO"), which is one of several independent regulators of the UK press, was subjected to JR. ${ }^{141}$ Though the court did not formally decide the jurisdictional point, Warby $\mathrm{J}$ allowed JR to proceed in spite of the fact that IPSO has not been recognised by the statutory Press Recognition Panel and his own recognition that "the argument against IPSO decisions being amenable to [JR] is stronger than it was in the case of the Jockey Club". ${ }^{142}$ Though it operates in the public interest, IPSO does not operate a monopoly and the court doubted that government would step in if it did not exist, as the Leveson Report did not recommend state regulation of the press. ${ }^{143}$ This might be seen as a further enlargement of the scope of JR which, in fact, goes beyond SGBs.

Therefore, allowing JR of SGBs would not be at odds with existing case law and would, in fact, make it more coherent-that they are not considered amenable is anomalous.

\subsubsection{The comparative argument}

It is also relevant that other jurisdictions have recognised the public function of SGBs. In French law, sports disciplinary sanctions are classed as administrative acts which can therefore only be reviewed by the administrative courts, ${ }^{144}$ while in Spain the public nature of sport is recognised in constitutional law ${ }^{145}$ and there is a specific administrative court dedicated to resolving sports regulatory disputes. ${ }^{146}$

Turning to other common law jurisdictions, the High Court of Australia allowed JR of an SGB in Forbes $v$ NSW Trotting Club, ${ }^{147}$ where the function of controlling the sport-“a public activity"-was considered significant. The same position has been reached in New Zealand, ${ }^{148}$

\footnotetext{
141 Coulter $v$ Independent Press Standards Organisation [2018] EWHC 1017 (Admin).

142 Ibid. [33].

143 Ibid. [35].

144 Van Kleef (2015), 11-12.

145 Ley 10/1990, de 15 de octubre, del Deporte.

146 El Tribunal Administrativo del Deporte.

147 [1979] HCA 27.

148 Finnigan v NZRFU; Le Roux v NZRFU (1995) unreported, 14 March; Loe v NZRFU (1993) unreported, 10 August.

149 Vancouver Hockey Club Ltd v Hockey Ventures Inc. (1987) 18 BCLR 2d 372 (BCSC).
}

Canada, ${ }^{149}$ South Africa ${ }^{150}$ and, albeit to a limited extent, ${ }^{151}$ the USA. ${ }^{152}$ The English position thus appears to be an anomaly, "unjustifiably lagging behind its Commonwealth counterparts". 153

The argument here runs deeper than simply saying "they do it, so we should do it". The crucial point is that these jurisdictions have recognised the public flavour of SGBs: they have recognised why SGBs properly fit into the public sphere. SGBs have much the same role and powers world over, so it appears incongruous that English law is asking the same question and getting a different answer. This is particularly significant as regards the other common law jurisdictions, as the principles at play are broadly the same. That England is the odd one out is telling.

Most concerning perhaps is that JR of SGBs has long been available in Scotland. ${ }^{154}$ Of course, Scots law does not distinguish between public and private law in the same way as English law, which may account for the different result, but it nonetheless sits uncomfortably given the geographical proximity of the jurisdictions. Indeed, in some sporting contexts, athletes from the two jurisdictions compete together, under a single SGB. ${ }^{155}$ It was held in Lennox $v$ British Show Jumping Association ${ }^{156}$ that such bodies would be reviewable in Scotland. This results in "forum shopping" ${ }^{157}$ whereby a party will simply seek to claim in the most favourable jurisdiction. Such inconsistencies are unsatisfactory and, for example, could lead to the situation whereby athletes of the same nationality, in the same sport, might have differing legal remedies available to them simply because of the team/SGB of which they are a member.

The fact that so many other jurisdictions have recognised the public flavour of SGBs certainly makes Aga Khan appear anomalous. However, Hoffman LJ was not drawn by comparative arguments:

different countries draw the line between public and private regulation in different places. The fact that certain functions of the Jockey Club could be exercised by a statutory body and that they are so exercised in some other countries does not make them governmental functions in England. ${ }^{158}$

\footnotetext{
150 Jockey Club of South Africa v Forbes [1992] ZASCA 237.

151 Kelly (2011), 74.

152 Finley v Kuhn (1978) 439 US 876 (7th Cir).

153 Armstrong (2008), 73.

154 St Johnston FC v Scottish Football Association, 1965 SLT 171.

155 E.g. The British Olympic Association.

1561996 SLT 353.

157 Munro (2005), 683.

158 Aga Khan, 932.
} 
While it is certainly true that different jurisdictions approach the public/private divide differently, comparative analysis in this field has particular value. The sports industry is truly international: athletes from England and Wales regularly compete against athletes from other jurisdictions and the fact that foreign athletes can access JR might give them an advantage — as explained in Part 4-which adds to the case for JR. It is surely desirable to enhance consistency in international sports law generally, especially when there are good, principled reasons for doing so. To do so is in the interests of both the administrators and participants of sport globally.

The court's approach in Aga Khan is out of date, and it is time to follow our Commonwealth counterparts.

\subsubsection{To what extent?}

Having argued that SGBs should be amenable to JR, it is important to consider to what extent they would be so. For an application for JR to succeed, not only must the body be susceptible to JR, but so must the specific decision in question. ${ }^{159}$ A public body in the modern day exercises many functions, some of which will not be "public" — such as entering employment contracts-and these will not be judicially reviewable. ${ }^{160}$

SGBs similarly perform a multitude of functions. Many operate their national team and, as such, undertake an array of commercial tasks such as negotiating sponsorship and paying players. Such purely commercial functions would be outside the scope of JR. It is only the regulatory function of SGBs which should be reviewable - only in this regard can their function be described as "public".

\section{Private law remedies}

The final issue which must be considered is the availability of private law remedies. In Aga Khan, Hoffman LJ stated that the existence of "entirely adequate" remedies in private law meant that no injustice would be caused by the denial of a public law remedy. ${ }^{161}$ This appears to allow the argument that private law remedies in the sporting context are, in fact, inadequate and, as such, JR should be allowed. However, he also stated that JR should not be used "to patch up" remedies available against bodies which would otherwise not be amenable to JR. ${ }^{162}$ Indeed, this seems to be the approach adopted

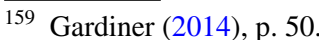

160 Walsh.

161 Aga Khan, 933.

162 Ibid.
}

consistently by English courts. ${ }^{163}$ As Lord Oliver explained in Leech v Deputy Governor of Parkhurst Prison, ${ }^{164}$ alternative remedies are relevant to the court's decision to permit JR, but not to the prior question of amenability. ${ }^{165}$

Therefore, the inadequacy of private law remedies cannot by itself make the case for amenability, but is relevant to the broader question of whether SGBs should be subject to JR. As such, this Part will highlight the limitations of the private law causes of action used to challenge SGBs, both substantive and procedural, and will argue that they should not preclude a claim for JR. This will demonstrate that the debate in Part 3 is not purely academic ${ }^{166}$ : there are practical reasons why an aggrieved sports participant would want to pursue JR as opposed to a private law cause of action.

On this view, sporting claimants have rights in both public and private law. This might be thought odd in the light of the procedural exclusivity rule, ${ }^{167}$ but, though a claim cannot be brought in public and private law simultaneously, the harshness of this rule has been mitigated ${ }^{168}$ such that a claim is unlikely to be struck out simply for using the "less appropriate" procedure. ${ }^{169}$ Indeed, in Clark $v$ University of Lincolnshire and Humberside,${ }^{170}$ Sedley LJ considered that, though JR could have been sought, a claim in private law was just as appropriate as there was simply "a contractual relationship which happens to possess a public law dimension". ${ }^{171}$ The same can be said of the participant-SGB relationship. It is argued that rights against SGBs may arise in public and private law ${ }^{172}$ and, as such, that litigants should be able to mount their claim depending on which jurisdiction would provide the better remedy in the circumstances. Indeed, this is the approach taken in New Zealand. ${ }^{173}$

\subsection{Private law causes of action}

Claims for breach of contract, restraint of trade and in the socalled private law "supervisory jurisdiction" have proved to be the primary mechanisms for challenging SGBs in English

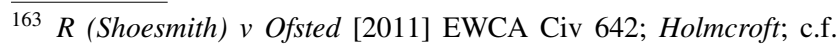
Datafin.

164 [1988] AC 533, 580.

165 Williams (2017b), 20.

166 Beloff et al. (2012), p. 261.

167 O'Reilly v Mackman [1983] 2 AC 237.

168 Beloff et al. (2012), pp. 265-266; Trim v North Dorset DC [2010] EWCA Civ 1446 [21].

169 Clark v University of Lincolnshire and Humberside (n 81), [39]. Elliott and Varuhas (2017), pp. 490-494.

170 Ibid.

171 Ibid. [16].

172 Beloff et al. (2012), p. 262.

173 Armstrong (2008), 96-97.
} 
law and, as such, will be considered here. However, challenges could also be mounted to varying degrees in the contractual "public policy" jurisdiction, ${ }^{174}$ competition law ${ }^{175}$ and EU law-though the latter would also be possible in JR.

\subsubsection{Breach of contract}

As explained above, SGB regulations are readily interpreted as contracts. ${ }^{176}$ Though this is somewhat artificial, it is a fiction the law has adopted consistently, out of necessity. Without an express or implied contract between the SGB and the participants, SGBs would have no legal basis for the exercise of its powers ${ }^{177}$ - participants could simply choose not to accept SGB regulatory decisions, and sport would descend into chaos. As merely de facto public bodies, SGBs must rely on private law.

As such, courts can perform a degree of review via claims for breach of contract. Some SGBs today explicitly prescribe the principles of natural justice and procedural fairness in their regulations. ${ }^{178}$ Thus, a decision might be challenged as a breach of an express contractual term. A court could then make a declaration as to the validity of the decision and remedy any ill-effects by awarding an injunction and/ or damages. ${ }^{179}$

Equally, the courts have shown themselves willing to imply the principles of natural justice into SGB regulations. ${ }^{180}$ Indeed, "public law principles" were implied into contracts at the highest level in Braganza $v$ BP Shipping, ${ }^{181}$ to conduct a review "almost indistinguishable from the general approach to review of public powers". ${ }^{182}$ This mirrors the view of Lord Woolf MR in Modahl v British Athletics Federation (No. 1$)^{183}$ that there is:

no reason why there should be any difference as to what constitutes unfairness or why the standard of fairness required by an implied term should differ from that required of the same tribunal under public law ${ }^{184}$

It can thus be said with confidence that the substance of the obligations owed by SGBs as a matter of private law is

\footnotetext{
$\overline{174}$ Edwin Peel, Treitel on The Law of Contract (14th edn, Sweet and Maxwell 2015), p. 549.

175 Boyes (2017), pp. 366-367.

176 E.g. Korda v ITF (1999) unreported, 29 January; Jones $v$ WRFU.

177 James (2017), p. 30.

178 E.g. RFU Regulation 19.1.6; British Cycling Disciplinary Rules.

179 James (2017), p. 39.

180 Jones $v$ WRFU; Wilander v Tobin [1997] 2 CMLR 346.

181 [2015] UKSC 17.

182 Elliott and Varuhas (2017), p. 143.

183 (1997) unreported, 28 July.

184 Ibid. pp. 17-18.
}

broadly the same as those they would owe if their decisions were amenable to JR. ${ }^{185}$

However, this may undermine one of the principal arguments in favour of precluding JR: that it would illegitimately cut across the intentions of the parties to the contract. ${ }^{186}$ After all, if contract law itself recognises that party autonomy is limited by principles equivalent to those of JR, how can the argument against the applicability of these principles in JR be maintained? One might argue that the court in Braganza was merely giving effect to the presumed intentions of the parties, but the reality is that the court went much further than that. ${ }^{187}$ These standards will invariably be applied "in the absence of very clear language" 188 to the contrary. In private law terms, it appears that these are terms implied "in law" into certain types of contract, rather than "in fact". Therefore, the argument in support of Aga Khan becomes difficult to sustain.

It is also a limit of the implied terms approach that parties could exclude their application through express terms. ${ }^{189}$ One might argue that the same "exclusion" could be achieved in JR via an ouster clause. However, given the restrictive interpretative approach taken by the courts to such clauses, ${ }^{190}$ it is suggested that an effective exclusion of the courts' jurisdiction would be less likely in public law. ${ }^{191}$

Of course, an action for breach of contract will only be available where a contract exists. Though the courts have been willing to imply contracts readily in the sports context, ${ }^{192}$ participants without a contract, such as those prevented from entering the sport in the first place, will have no remedy here. This action will also be of limited use to participants looking to challenge regulations themselves: only new regulations which the SGB makes ultra vires could be challenged. When an action for breach of contract is unavailable, JR would provide a remedy.

\subsubsection{Restraint of trade}

An associated mechanism for challenging SGBs is the doctrine of restraint of trade. According to the leading case,

\footnotetext{
185 Kleef (n 145), 8.

186 Elliott and Varuhas (2017), p. 145.

187 In any event, it is unrealistic to suggest intentions can be presumed from such a fictional contract.

188 BT v Telefónica O2 UK [2014] UKSC 42 [37].

189 Elliott and Varuhas (2017), p. 145.

190 Anisminic v Foreign Compensation Commission [1969] 2 AC 147.

191 This is subject to the general exclusion of the courts entailed by an arbitration clause-Stretford $v$ FA. However, there is some doubt over this following Mutu and Pechstein.

192 Modahl.
} 
Nordenfelt v Maxim Nordenfelt Guns and Ammunition Co, ${ }^{193}$ a contractual term which places a restraint on the exercise of an individual's trade will be void unless it can be justified as reasonable by reference to the interests of the parties and the interests of the public. ${ }^{194}$ It has evolved as a public policy tool to protect individual autonomy and has been extended to non-contractual cases. ${ }^{195}$ It can be used to challenge not only SGB decisions, ${ }^{196}$ but also regulations themselves. ${ }^{197}$ Though it does not give rise to an action for damages, courts can make declarations as to validity ${ }^{198}$ and may be able to award an injunction. ${ }^{199}$

However, the doctrine is not without its limitations. Firstly, it is not always clear where the burden of proof lies in sports cases, nor how the standard of reasonableness should be formulated. ${ }^{200}$ In Stevenage Borough FC v The Football League, ${ }^{201}$ Carnwath J suggested that the burden was on the individual seeking to challenge the provision, adopting a reasonableness standard influenced by JR, ${ }^{202}$ but in Newport AFC v Football Association of Wales ${ }^{203}$ the court treated the issue using orthodox contractual principles, with the onus on the SGB to justify the rule. There is still no "universal and immutable standard of review". ${ }^{204}$ Such uncertainty makes the doctrine unappealing.

Its greatest limitation, though, is that it is confined to cases concerning "trade". ${ }^{205}$ In Ray v PGA Ltd., ${ }^{206}$ the court held that the doctrine did not apply because the claimant's contract was a "training" contract, not a "trading" contract. ${ }^{207}$ More famously, British sprinter Dwain Chambers was refused an interim injunction to enable him to compete at the 2008 Olympics, in part, because the Olympic Games is an amateur event. ${ }^{208}$ The court held that, even if it could be argued that his Olympic participation could give rise to

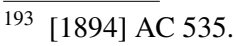

194 Beloff et al. (2012), p. 73.

195 Pharmaceutical Society v Dickson [1970] AC 403.

196 Lewis and Taylor (2014), p. 922.

197 E.g. Eastham v Newcastle United FC [1964] Ch 413.

198 Lewis and Taylor (2014), p. 92.

199 Newport AFC v Football Association of Wales [1995] 2 All ER

87.

200 Beloff et al. (2012), p. 74.

201 (1996) 9 Admin LR 109.

202 [2006] ISLR, SLR 128 [60].

203 (1995) unreported, 12 April.

204 Beloff et al. (2012), p. 72.

205 E.g. Ray v Professional Golfers Association (1997) unreported,

15 April.

206 Ibid.

207 Beloff et al. (2012), p. 74.

208 Chambers v British Olympic Association [2008] EWHC 2028 (QB). an "indirect financial benefit", Chambers" "prospects of success" at the Olympics were "at best, speculative", such that it would be difficult to argue that there was any restraint of trade. ${ }^{209}$ As Mackay J put it, "his prospects of arguing...that this is a right to work case are not good". 210

This was built on the decision of Gasser $v$ Stinson, ${ }^{211}$ where it was held that the restraint of trade doctrine could not apply where an athlete was merely deprived of a "chance of building up a reputation and to later exploit it for commercial gain" but that it would apply where an athlete was prevented from participating in a competition from which they otherwise would have been able to make a financial gain as a "direct consequence". Therefore, amateur athletes, or athletes competing at such a level that they are unable to be sure of obtaining any direct financial gain from their participation, may be left without a remedy under restraint of trade. In such circumstances, JR could provide a meaningful alternative.

\subsubsection{The supervisory jurisdiction}

Given the possible vacuum in the law where those affected by SGB regulations are not in a contractual relationship with the $\mathrm{SGB},{ }^{212}$ English private law appears to have developed a residual "supervisory jurisdiction". In Bradley v Jockey $C l u b,{ }^{213}$ affirmed on appeal, ${ }^{214}$ it was held that, even in the absence of a contractual relationship, an SGB decision "is subject to the supervisory jurisdiction of the court in accordance with the principles stated in Nagle v Feilden". 215

In Nagle, Lord Denning MR stated that courts may have a jurisdiction to see that exercise of "predominant power over... a trade or profession...is not abused" 216 as a matter of public policy. Indeed, in Bradley, Richards $\mathrm{J}$ noted that this area has assumed "even greater importance" given the attitude of the courts towards the JR of SGBs. ${ }^{217}$ He stated:

given the difficulties that sometimes arise in drawing the precise boundary between the two, I would consider it surprising and unsatisfactory if a private law claim in relation to the decision of a domestic

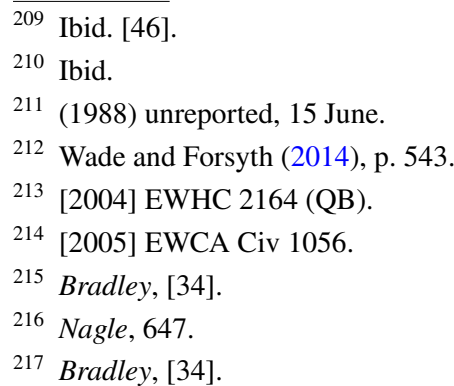


body required the court to adopt a materially different approach from a judicial review claim $^{218}$

As such, under this supervisory jurisdiction, the court may review both procedural and substantive fairness and make a declaration as to the "lawfulness of the decision taken"219 regardless of the existence of a contract.

Nonetheless, the scope and basis of this jurisdiction were not entirely clear following Bradley, with particular uncertainty over whether it was limited to cases concerning the claimant's right to work. However, in Mullins $v$ McFarlane and The Jockey Club, ${ }^{220}$ it was held that there was "no jurisdictional...boundary to the power of the Court to grant declaratory relief in this context" 221 -it was not so restricted. It thus appears incredibly broad, and it may be that the matter need only be of "importance". ${ }^{222}$ It was exercised in both Fallon $v$ Horseracing Regulatory Authority ${ }^{223}$ and McKeown v British Horseracing Authority, ${ }^{224}$ but remains a relatively unexplored area, raising a plethora of questions.

Primarily, its basis remains uncertain. Bradley placed great reliance on Nagle, which itself was a "restraint of trade" case, ${ }^{225}$ but the jurisdiction has been construed far more broadly. Bradley may have elided restraint of trade with the court's general jurisdiction to grant a declaration (now under CPR 40.20), ${ }^{226}$ a point of confusion evident throughout the case law. In McInnes v Onslow-Fane 227 "public law principles" were seemingly applied under the court's general jurisdiction, but the court drew heavily on Nagle and restraint of trade. ${ }^{228}$ Likewise, JR principles were injected into restraint of trade in Nagle and Stevenage Borough FC. It may be that in Nagle and Onslow-Fane, the courts were seeking a basis for the grounds of review necessary to do justice and so resorted to the doctrine of restraint of trade, as opposed to relying specifically on the court's general jurisdiction. ${ }^{229}$ Indeed, Hoffman LJ thought there was "an improvisatory air" 230 about the solution in Nagle.

\footnotetext{
218 Ibid. [37].

219 Ibid.

220 [2006] EWHC 986 (QB).

221 Ibid. [39].

222 Boyes (2017), 366.

223 [2006] EWHC 2030 (QB).

224 [2010] EWHC 508 (QB).

225 Nagle, 644.

226 Lewis and Taylor (2014), p. 935.

227 [1978] 1 WLR 1520.

228 Ibid. 1528

229 Lewis and Taylor (2014), p. 936.

230 Aga Khan, 933.
}

The result is that there is a significant lack of clarity over the true basis of the jurisdiction expounded in Bradley and Mullins. This is unsatisfactory and may be practically significant in determining whether amateurs can claim, whether regulations as well as decisions can be challenged, and where the burden of proof lies. Indeed, in Bradley, Richards $\mathrm{J}$ deliberately left the question of the burden open. ${ }^{231}$ Yet, as he noted, such difficulties would evaporate if JR applied. ${ }^{232}$ At the time of Nagle and Onslow-Fane, the scope of JR was more limited than it is now-had the functional approach to amenability existed, it would surely have provided the more natural solution. ${ }^{233}$

Moreover, if it is based on restraint of trade, a broad jurisdiction as suggested in Mullins would seem to extend a field of public policy; something which, on orthodox private law principles, is controversial ${ }^{234}$ - particularly without proper consideration of the reasons for doing so. Recognising that SGBs are exercising a de facto public function would give a principled justification for review.

There are thus many question marks hanging over the supervisory jurisdiction. There is a confused body of law which has the effect of providing JR "by the back door"; an intellectually unsatisfactory approach and one likely to cause difficulties in practice. Accepting JR of SGBs, it is submitted, would be preferable.

\subsubsection{Substantive assessment}

Each of the private law causes of action discussed has its merits, but also limitations. Particular uncertainty lies over restraint of trade and the supervisory jurisdiction, largely owing to attempts to infuse the private law with public law principles. Allowing JR of SGBs would obviate the need to perform contortions in private law: it has a body of rules which could readily be applied to SGBs in a transparent and principled way, with no need for adjustment, regardless of the applicant's status (professional or contractual), and by judges skilled in their application. ${ }^{235}$

Furthermore, mounting a challenge to the regulations themselves would be more straightforward in JR. Indeed, in Aga Khan, Farquharson LJ suggested that:

If for example the JC failed to fulfil its obligations under the charter by making discriminatory rules, it

\footnotetext{
231 Bradley, [35].

232 Ibid. [33].

233 RAM Racecourses, 246-247 (Brown J).

234 Peel (2015), p. 550.

235 Pannick (1997), 153.
} 
may be that those affected would have a remedy in public law ${ }^{236}$

In JR, SGB regulations could be substantively challenged on the well-recognised grounds of fundamental rights, ${ }^{237}$ Wednesbury reasonableness ${ }^{238}$ or proportionality, ${ }^{239}$ though discrimination claims could today be brought under Part 7 of the Equality Act 2010. Successful challenges to SGB regulations have been scarce in the contractual and supervisory jurisdictions, ${ }^{240}$ while restraint of trade is limited. JR would provide a reliable means of challenge, including for amateur athletes.

The remedial differences are also salient. In contract, the available remedies are comprehensive: damages, injunctions or a declaration. In the supervisory jurisdiction, however, applicants can only obtain a declaration. Though a declaration can be a "highly effective weapon", ${ }^{241}$ its effect may be limited in a non-contractual context. One cannot be in contempt of court for ignoring a declaration ${ }^{242}$ and, if there is no contract, there remains no basis upon which to claim an injunction. It is therefore unclear just how effective a remedy this would be, albeit that there would be public pressure on SGBs to comply.

By contrast, in JR, declarations and injunctions, ${ }^{243}$ as well as mandatory, prohibiting and quashing orders, ${ }^{244}$ are available. The latter would be particularly powerful in undoing the effects of sanctions, though would largely have the same effect in practice as an injunction. Remedies in JR are certainly more powerful than those under the supervisory jurisdiction, though both are discretionary, while the principal difference with the contractual jurisdiction is compensation - in JR, damages are rarely available. ${ }^{245}$ However, they are not usually the most important remedy for sporting claimants ${ }^{246}$ and, in any event, if cases must be brought within the short time limit of JR and are disposed of quickly, the potential for significant losses to accrue is less likely.

\footnotetext{
236 Aga Khan, 930.

${ }^{237} R v$ Secretary of State for the Home Department, ex p. Simms [2000] 2 AC 115.

238 Associated Provincial Picture Houses $v$ Wednesbury Corporation [1947] 2 All ER 680.

${ }^{239} R$ (Daly) $v$ Secretary of State for the Home Department [2001] 2 AC 532 .

240 Boyes (2017), 372.

${ }^{241}$ Beloff et al. (2012), p. 276.

${ }^{242}$ McMullen (2019).

243 S.31(2) SCA 1981.

244 CPR 54.2.

${ }^{245} R$ (Quark Fishing) v Secretary of State for Foreign and Commonwealth Affairs (No. 2) [2006] 1 AC 529 [94-96].

246 Beloff et al. (2012), p. 268. The most important remedy is usually the sanction being overturned.
}

\subsection{Procedural matters}

The JR procedure is often conceived as providing protection to defendant public bodies, which are politically accountable and whose effectiveness would be hindered by the threat of ordinary litigation. ${ }^{247}$ Oliver has argued that there is no reason why SGBs should benefit from such protection ${ }^{248}$ but, given the softening of the procedural exclusivity rule, this protective function has diminished in importance for de facto SGBs, as appropriate claims outside of the JR time limit may nonetheless be brought in private law.

It must also be recognised that JR procedure may bring advantages for claimants, especially in the sporting context. Three procedural points of difference add force to the argument that private law remedies are not necessarily adequate, and JR more suitable.

\subsubsection{Hearing procedure}

Firstly, the JR hearing procedure is far better suited to sports disputes than that of private law, as recognised by Carnwath $\mathrm{J}$ in Stevenage Borough FC:

in spite of the efforts of the parties, and the economy of presentation, the writ procedure, with pleadings, discovery and oral evidence, inevitably is more elaborate, time consuming and expensive than judicial review... [where] the case for each party can generally be set out in one main affidavit...supported only by relevant documents; rather than, as in this case, in some 16 witness statements, 15 files of documents and transcripts of 5 days of oral evidence ${ }^{249}$

$\mathrm{JR}$ is a far more expedient and inexpensive process, factors which may be of great pertinence for athletes, clubs and even SGBs themselves. The speed at which the sports industry moves makes swift dispute resolution vital for both participants and SGBs, ${ }^{250}$ so the availability of JR would be of real significance.

Of course, there are ways to expedite private law proceedings. CPR changes have permanently established Shorter and Flexible Trials schemes, ${ }^{251}$ allowing for a "simplified" procedure which can offer dispute resolution "on a commercial timescale". ${ }^{252}$ These might well be appealing to sporting

\footnotetext{
${ }^{247}$ Elliott and Varuhas (2017), p. 477.

248 Oliver (1997).

249 (1996) 9 Admin LR 109.

250 Beloff et al. (2012), pp. 268-269.

${ }^{251}$ CPR Practice Direction 57AB.

252 '100th Update to the Civil Procedure Rules' (Justice) $<$ https ://www.justice.gov.uk/courts/procedure-rules/civil> Accessed 15 March 2019.
} 
claimants, but importantly only apply if the parties mutually agree. Thus, procedure could be used as a negotiating tool by defendant SGBs in order to draw out proceedings and deter litigation. There is no such opportunity for manipulation in JR. Part 8 CPR proceedings might be more appealing, as they allow for a procedure similar to JR where there is no dispute of fact. However, a defendant can still object to its use, ${ }^{253}$ and the starting point remains that evidence will be heard orally and that any preliminary ruling on written evidence will be temporary. ${ }^{254}$

Of course, interim injunctions and declarations can be obtained in private law under Part 25 CPR, which offers swift protection where appropriate. However, such interim determinations tend to favour claimants, while SGBs typically fare better at trial. ${ }^{255}$ It is also unclear whether interim measures are available in the supervisory jurisdiction. ${ }^{256} \mathrm{~A}$ streamlined process of JR would avoid any such inconsistencies, allowing for swift and, most importantly, final dispute resolution.

\subsubsection{Standing}

Secondly, JR's broad test of standing ${ }^{257}$ may be of importance in the sports context. In private law, the only person entitled to sue is the person whose right has been infringed. ${ }^{258}$ In public law, by contrast, a court will likely allow any applicant to proceed where they have a strong prospect of succeeding on the merits. ${ }^{259}$

As noted in Part 3, there is a huge public interest in sport. Thus, there is a strong argument for allowing challenges to SGBs to be made not only by the participants whose rights have been affected, but also interested parties more generally. Clubs are backed by passionate fans, athletes are represented by unions, ${ }^{260}$ and both are often supported commercially. In cases where athletes or clubs cannot afford, or choose not to mount a legal challenge, such groups may wish to. This was the central issue in Finnigan $v$ NZRFU where individuals not in a contractual relationship with the

253 CPR 8.8.

254 Beloff et al. (2012), pp. 261-262.

255 Ibid.

256 International General Electric Co of New York v Commissioners of Customs \& Excise [1962] Ch 784; c.f. Transport for London v Griffin [2012] EWHC 1105 (QB).

${ }^{257} R$ v Inland Revenue Commissioners, ex $p$ National Federation of Self-employed and Small Businesses [1982] AC 617.

258 Subject to limited provision for "public interest interventions" in private law matters on appeal to the Supreme Court (Rule 26 SCR 2009).

259 Wade and Forsyth (2014), p. 587.

${ }^{260}$ E.g. The Rugby Players Association; Professional Footballers' Association.
SGB were held to have standing, paving the way for JR of SGBs in New Zealand. These groups can be considered to have an interest in SGB decisions and would be best placed to vindicate that through JR.

\subsubsection{Time limits}

Finally, it is worth commenting on the 3-month limitation period in JR. ${ }^{261}$ This short time limit would be no object in the sports context, as urgency is invariably essential ${ }^{262}$ due to the fast-moving nature of the industry. Indeed, where it is a sporting suspension being challenged, claims will need to be made almost immediately.

\subsubsection{Procedural assessment}

Given the foregoing, it is submitted that private law remedies will not always be adequate for challenging SGBs. The more straightforward procedural requirements of JR are particularly well suited to the sports sector, where disputes "arise at short notice... [and] where the swiftness of the court's ruling is as important as the result itself" $" 263$ and where interested parties might not have private law standing. JR can provide a final ruling within weeks or even days of the challenged decision. ${ }^{264} \mathrm{JR}$ is arguably the "preferable vehicle" for sports dispute resolution. ${ }^{265}$

However, it must be acknowledged that it is a scarce resource. Unlike claims in private law, which can in theory be presented in any county court, there are only five administrative courts to handle JR claims nation-wide. As such, delays are common, somewhat offsetting the procedural advantages. Nonetheless, the lower-cost and conclusive nature of JR remains significant, and applications can be heard more swiftly in urgent cases. ${ }^{266}$ In the situation where an SGB makes an unlawful decision late one evening prohibiting an individual from competing the following morning, JR could provide an effective remedy.

\subsection{Arbitration}

The role of private law in sport cannot be adequately considered without mention of arbitration. The past two decades have seen arbitration emerge as the primary means of dispute resolution for many SGBs and, certainly, for doping

\footnotetext{
261 CPR 54.5

262 Beloff et al. (2012), p. 261.

263 Ibid. pp. 268-269.

264 Ibid. p. 261

265 Ibid. p. 266

266 A Queen's Bench judge is on duty $24 \mathrm{~h}$ a day to hear applications for JR which cannot be delayed until normal hours of business.
} 
disputes. As such, it might be thought that the role JR would play would be merely residual and that arbitration clauses will pose an insurmountable hurdle to any challenge in the ordinary courts, in private or public law. ${ }^{267}$ This may be true in some cases, but it does not preclude the need for JR.

Firstly, not all SGBs use arbitration. For example, the RFU and, indeed, World Rugby (rugby union's international governing body, which is governed by English law ${ }^{268}$ ) make no provision for arbitration outside of anti-doping, while British Cycling provides for it on a purely voluntary basis. As such, there will remain circumstances in which arbitration is irrelevant, and the ordinary courts' jurisdiction will be the only forum for challenges to SGBs.

Secondly, the validity of "forced arbitration" clauses contained in SGB regulations has been cast into doubt by the ECtHR decision in Mutu and Pechstein, ${ }^{269}$ which recognised the lack of genuine consent by participants to SGB regulations. This reinforces the analysis in Part 3.1.1 with regard to the artificiality of the contract deemed to exist between participants and SGBs and may lay the foundation for a future challenge to the validity of SGB arbitration clauses in English law. Moreover, it is suggested that, if JR of SGBs is accepted, the administrative courts might be more willing to find arbitration clauses invalid, owing to their approach to ouster clauses. ${ }^{270}$

Arbitration has and will continue to have a significant role to play in sports dispute resolution, and there are many good reasons for that. However, it is argued that it does not do away with the need for, nor does it preclude, JR.

\subsection{Overall assessment}

In sum, it is argued that the availability of private law remedies should not preclude claims for JR, as they are not necessarily adequate, substantively or procedurally. Allowing JR of SGBs would bring the advantages of both coherence and speed. ${ }^{271}$ The choice of remedy should be at the discretion of the claimant whose rights have been infringed.

\section{Conclusion}

On the basis of the foregoing analysis, it is argued that regulatory decisions of SGBs should be subject to JR. The reasoning of the decision in Aga Khan suffers from a number of fatal flaws undermining its authority. Its reasoning on the consensual relationship between participants and SGBs is highly unsatisfactory, and its emphasis on the source of the power is inappropriate. The exclusion of SGBs from the scope of JR is also out of line with other jurisdictions as well as English authorities on other self-regulatory organisations. Most significantly, since the early 1990s, government involvement in sport has grown inexorably such that SGBs' public function can now be straightforwardly established. In 1991, Rose J considered that allowing JR of SGBs would be "a quantum leap". ${ }^{272}$ In 2019, continuing to deny JR of SGBs would be a categorical mistake.

Of course, there will still be sports cases that can be dealt with in private law, and it is not suggested that JR be used exclusively. However, the availability of private law remedies should not preclude JR, particularly as it will often offer a more appealing remedy, and, if an application is brought properly, there is no reason for it to be denied. New Zealand's approach should be followed.

Finally, the analysis in Part 4.1 demonstrates the substantive overlap between the traditionally conceived fields of public and private law. The position of SGBs, and their more recent treatment by English courts, supports the view ${ }^{273}$ that any substantive divide between the two spheres is not strict. The principal divide appears procedural. Though this, too, has been softened, significant procedural distinctions do exist and, for as long as that remains the case, sporting claimants should be able to challenge SGBs in both jurisdictions.

Acknowledgements This publishing of this paper would not have been possible without the insightful supervision of Dr. Joanna Bell (St John's College, Cambridge). I thank her for the expert guidance she provided and for challenging me so thoroughly throughout the research and writing processes. I would also like to thank Professor Trevor Allan (Pembroke College, Cambridge) and Dr. Shona Stark (Girton College, Cambridge) for their feedback on my paper. Any errors are wholly mine.

Open Access This article is licensed under a Creative Commons Attribution 4.0 International License, which permits use, sharing, adaptation, distribution and reproduction in any medium or format, as long as you give appropriate credit to the original author(s) and the source, provide a link to the Creative Commons licence, and indicate if changes were made. The images or other third party material in this article are included in the article's Creative Commons licence, unless indicated otherwise in a credit line to the material. If material is not included in the article's Creative Commons licence and your intended use is not permitted by statutory regulation or exceeds the permitted use, you will need to obtain permission directly from the copyright holder. To view a copy of this licence, visit http://creativecommons.org/licenses/by/4.0/.

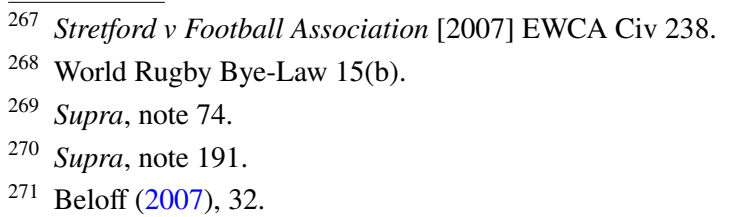

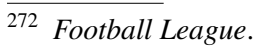

${ }^{273}$ E.g. Oliver (2002).
} 


\section{References}

Anderson J (2006) An accident of history: why the decisions of sports governing bodies are not amenable to judicial review. Common Law World Rev 35:173-196

Armstrong R (2008) The whistle has blown...game over...or is it really? Challenging the decisions of sports governing bodies in New Zealand. Canterb Law Rev 14:65-100

Beloff M (2006) Editorial. Int Sports Law Rev 1:1-3

Beloff M (2007) Editorial. Int Sports Law Rev 3:31-32

Beloff M, Kerr T (1996) Why Aga Khan is wrong. Judic Rev 1:30

Beloff M, Kerr T, Demetriou M, Beloff R (2012) Sports law, 2nd edn. Hart, Oxford

Boyes S (2017) Sports in court: assessing judicial scrutiny of sports governing bodies. Public Law July:363-381

Department for Digital, Culture, Media \& Sport (2015) Sporting future-a new strategy for an active nation

Department for Digital, Culture, Media \& Sport (2018) Government response: the government must introduce an independent regulator for English football. Petitions UK Government and Parliament. Retrieved 14 March, 2019, from https://petition.parliament.uk/ petitions/213108?reveal_response=yes

Digital, Culture, Media \& Sport Committee (n.d.) Match fixing in tennis inquiry. UK Parliament. Retrieved 14 March, 2019, from https://www.parliament.uk/business/committees/committees-a-z/ commons-select/culture-media-and-sport-committee/inquiries/ parliament-2015/inquiry/

Digital, Culture, Media \& Sport Committee (n.d.) Sport governance inquiry. UK Parliament. Retrieved 14 March, 2019, from https:// www.parliament.uk/business/committees/committees-a-z/commo ns-select/digital-culture-media-and-sport-committee/inquiries/ parliament-2017/sports-governance-17-19/

Elliott M (2012) Judicial review's scope, foundations and purposes: joining the dots. New Zealand Law Review, pp 75-112

Elliott M, Varuhas J (2017) Administrative law, 5th edn. OUP, Oxford

FA (2013) Protocol on the appropriate handling of incidents falling under both criminal and football regulatory jurisdiction. The FA. Retrieved 4 November 2019, from http://www.thefa.com/-/media /files/pdf/the-fa-2013-14/governance/crown-prosecution-fa-faw. ashx?la=en

Gardiner S (2014) Sports law in the United Kingdom. Kluwer, London

Gardiner S, O’Leary J, Welch R, Boyes S, Naidoo U (2012) Sports law, 4 th edn. Routledge, Oxford

House of Commons Culture, Media \& Sport Committee (2011) Football governance. HC 792

House of Commons Culture, Media \& Sport Committee (2014) Women and sport. HC 513

House of Commons Culture, Media \& Sport Committee (2017) Homophobia in sport. HC 113

House of Commons Digital, Culture, Media \& Sport Committee (2018) Combatting doping in sport. HC 366
James M (2017) Sports law, 3rd edn. Palgrave, London

Kelly E (2011) Judicial review of sports bodies' decisions: comparable common law perspectives. Int Sports Law Rev 4:71-75

Lewis QCA, Taylor J (2014) Sport: law and practice, 3rd edn. Bloomsbury Professional, London

McMullen J (2019) Declarations. Practical law. Retrieved 19 March, 2019, from https://uk.practicallaw.thomsonreuters. com/8-625-6364

Ministry of Justice (2018) 100th update to the civil procedure rules. Justice. Retrieved 15 March, 2019, from https://www.justice.gov. uk/courts/procedure-rules/civil

Morgan J (2012) A Mare's nest? The Jockey Club and judicial review of sports governing bodies. Leg Inf Manag 12(2):102-109

Munro C (2005) Comment: sports in the courts. Public Law, Winter, pp 681-684

Oliver D (1997) Common values in public and private law and the public/private divide. Public Law, Winter, pp 630-646

Oliver D (2002) Public law procedures and remedies-do we need them? Public Law Spring:91-110

Pannick D (1992) Who is subject to judicial review and in respect of what? Public Law Spring:1-7

Pannick D (1997) Judicial review of sports bodies. Judic Rev 2:150-153

Peel E (2015) Treitel on the law of contract, 14th edn. Sweet and Maxwell, London

Thompson L (2016) How to protect the integrity of sport—key points from the sports and sports betting integrity action plan. LawInSport. Retrieved 9 November 2019, from https://www.lawinsport .com/content/sports/item/how-to-protect-the-integrity-of-sport -key-points-from-the-sport-and-sports-betting-integrity-actio n-plan

UK Sport (n.d.) A code for sports governance. UK Sport. Retrieved 14 March, 2019 http://www.uksport.gov.uk/resources/governance -code

van Kleef R (2015) Reviewing disciplinary sanctions in sports. Camb J Int Comp Law 4(1):3-28

Verow R, Lawrence C, McCormick P (2005) Sports business: law, practice and precedents, 2nd edn. Jordan, Bristol

Wade W, Forsyth C (2014) Administrative law, 11th edn. OUP, Oxford

Williams A (2017a) Judicial review and monopoly power: some sceptical thoughts. Law Q Rev 133(October):656-682

Williams A (2017b) Public function and amenability: recent trends. Judic Rev 22(1):15-26

Woolf H (1986) Public law-private law: why the divide? A personal view. Public Law, Summer, pp 220-238

Publisher's Note Springer Nature remains neutral with regard to jurisdictional claims in published maps and institutional affiliations. 